\title{
Ecosystem Considerations for Postdisaster Recovery: Lessons from China, Pakistan, and Elsewhere for Recovery Planning in Haiti
}

\author{
$\underline{\text { Susan A. Mainka }}^{1}$ and $\underline{\text { Jeffrey McNeely }}^{1}$
}

\begin{abstract}
As the world joins forces to support the people of Haiti on their long road of recovery following the January 2010 earthquake, plans and strategies should take into consideration past experiences from other postdisaster recovery efforts with respect to integrating ecosystem considerations. Sound ecosystem management can both support the medium and long-term needs for recovery as well as help to buffer the impacts of future extreme natural events, which for Haiti are likely to include both hurricanes and earthquakes. An additional challenge will be to include the potential impacts of climate change into ecosystem management strategies.
\end{abstract}

Key Words: disaster recovery; ecosystems and livelihoods; Haiti

\section{INTRODUCTION}

On 12 January 2010, a devastating earthquake hit Haiti, which occupies the western half of the Caribbean island of Hispaniola. It left behind a swath of destruction in a country whose ability to recover was already severely compromised following years of poor environmental management. The prolonged process of recovery has been slowly moving from addressing immediate humanitarian needs to the mid and longer term objectives of restoring livelihoods. Lessons learned from previous disasters, such as the recent earthquakes in Pakistan and China, the Indian Ocean tsunami, and hurricanes Mitch and Katrina, provide evidence that integrating the role of the environment in both the immediate days after the disaster and longer term restoration of livelihoods is key to successful longterm recovery.

Disasters on the scale of the Haiti earthquake are becoming more common as human populations increase, the rate of climate change increases, and people occupy more vulnerable lands. On the other hand, modern technology is making information about these disasters, as well as the responses to them, more freely available for use in informing effective responses. Consider the 12 May 2008 disastrous earthquake that hit central China killing nearly 70,000 people, injuring 375,000, and leaving nearly 5 million homeless (Government of China
2008); the 26 December 2004 tsunami that killed tens of thousands of people in Indonesia, Thailand, India, and Sri Lanka; and the 8 October 2005 earthquake in Kashmir that killed 60,000 people and left 2.5 million homeless.

Human livelihoods are underpinned by the services provided by healthy ecosystems (MA 2005). Ecosystem services encompass a broad range of functions, from the tangible provision of the necessities of life, i.e., food, water, medicine, and clean air, to processes that pollinate crops, decompose waste, control noxious pests and diseases, and regulate extreme natural events. Ecosystem services were popularized by Stanford University conservation biologist Gretchen Daily (1997) and brought into the political mainstream by the Millennium Ecosystem Assessment. The latter adopted a framework that classified these services and analyzed the current state of their delivery and the drivers that affected their delivery. Ecosystem services are available without people necessarily being conscious of the many and complex processes involved in their production and delivery. Efforts to support the long-term sustainable supply of those services are as important to human well-being and survival as they are to nature itself.

This paper considers the impacts of extreme natural events on the environment and the services healthy ecosystems provide in support of human well-being 
as well as the opportunities that effective environmental management can bring to postdisaster recovery and to reducing longer term vulnerability. We review information available in the literature about several previous disasters and lessons learned from the International Union for Conservation of Nature (IUCN)'s experience working in the field on postdisaster environmental recovery to develop some principles for planning and action.

\section{THE ENVIRONMENT AND DISASTERS: VICTIM AND POTENTIAL SOLUTION}

The impact of extreme natural events such as earthquakes, tsunamis, and floods is felt by both people and the environment. Conversely, sound environmental management can help mitigate potential impacts by ensuring continued delivery of the services provided by nature upon which we depend.

Disasters resulting from extreme natural events affect not only people but also the ecosystems in which they live. Following China's Sichuan earthquake, an environmental assessment reported serious loss of forests due to landslides and significant alterations to water flows because of shifting river basins and the creation of 'quake lakes' when landslides dammed rivers and streams. The earthquake was centered in the MinshanHengduan Mountains, a key area of biodiversity conservation that is ecologically very sensitive and rich in species: 12 national first-class protected animals and 24 state-level rare and endangered plants have habitats there, including the iconic giant panda. In all, an estimated 80 percent of panda habitat in Sichuan was damaged in the quake (WRI 2008). Similarly, in Pakistan, following the 2005 earthquake, numerous landslides resulted in environmental degradation and created a natural lake in the Nhelum Valley that could increase future flooding risks (UN OCHA 2005).

The environmental damage resulting from a disaster brings consequences for the ecosystem services that are provided. For example, the 2004 tsunami in the Andaman Sea caused accumulated debris in lagoons in Hambantota, Sri Lanka, and other coastal ecosystems, plus salt intrusion inland, negatively affecting local fisheries and agricultural productivity (ADB 2005). In Sichuan, over 33,000 ha of crops were damaged and millions of livestock were killed. Dams and irrigation systems for some 100,000 hectares of rice fields and over 50,000 greenhouses were also damaged or destroyed. At the time of the earthquake, crop harvesting was underway in the most affected areas and a substantial part of the production was lost. Most of the populations affected by the earthquake were critically dependent on agriculture for their livelihoods and the earthquake undermined the food security of many tens of thousands of people (FAO GIEWS 2008).

For Haiti, ecosystem services have long been severely disrupted. Jared Diamond (2005) highlighted the plight of Haiti, one of the poorest countries in the world, and the striking environmental consequences of the country's management choices in comparison to their neighbors on the same island, the Dominican Republic (DR). In terms of human well-being, as measured by the Human Development Index (HDI), a national-level index compiled by the United Nations Development Programme (2010) based on health, education, income, inequality, poverty, gender, sustainability, and security indicators, the DR comes out considerably ahead $(0.663,88$ th out of 182 countries, whereas Haiti ranks 145 th, with an HDI of 0.404). In terms of environmental management, the DR has $28 \%$ forest cover, Haiti only $1 \%$. Terrestrial protected area coverage in the DR is $22 \%$ whereas Haiti identifies a total coverage of much less than 1\% (Millennium Development Goal indicator database accessed on 5 Feb 2010, http://mdgs.un.org/unsd/mdg/Data.aspx). These data were collected prior to the 2010 earthquake but give some indications of the inability of Haiti's degraded ecosystems to provide the services needed for recovery. Worse, these ecosystem services were further degraded by the earthquake and planning for recovery must include measures to restore these services.

Growing evidence indicates that sound environmental management decreases people's vulnerability to the impacts of extreme natural events such as hurricanes, tsunamis, floods, and earthquakes. A comparison of 'sustainable' vs. 'conventional' farms in Nicaragua following Hurricane Mitch determined that the 'sustainable' farms, i.e. those that practiced soil conservation and agroecological management practices, were more likely to haveless erosion and economic losses along with more topsoil and vegetation remaining (Holt-Giménez 2002). Danielsen et al. (2005) reported that coastal mangroves and Casuarina plantations attenuated tsunami waves and protected coastlines in the 
Andaman Sea. However, this service of coastal protection is not a linear function and the protective effect can depend on factors such as plant population density, tidal regimes, seasons, and latitudes (Koch et al. 2009). Current use of physical infrastructure for flood control results in decreased riverine habitat and filling in of wetlands. Both of these will result in decreases in other ecosystem services that could be more cheaply and sustainably provided by conserving the natural habitat (Opperman et al. 2009). These examples, among many that could be cited, show that making wiser use of ecosystems could both decrease risk to people and support delivery of ecosystem services. However, use of ecosystems as 'bioshields' is not a panacea for decreasing people's vulnerability to natural disasters and should be accompanied by other measures such as early warning systems and disaster preparedness (Feagin et al. 2010). The opportunities that effective ecosystem management provides in terms of decreasing vulnerability of both people and ecosystems to future extreme events should be given high priority in disaster management planning.

\section{DISASTER RECOVERY PLANNING AND THE ENVIRONMENT}

As important and urgent as human needs are, both short-term and long-term recovery efforts should also take into account the needs of nature in support of improving human well-being. Reconstruction efforts following disasters often provide opportunities to bring about more far-reaching and longer term changes. These changes will both aid recovery of people's livelihoods and the ecosystems on which many rely and decrease vulnerability to future disasters. Those involved in the reconstruction now have a window of opportunity to begin reconstructing sustainable livelihoods based on healthy ecosystems. To make the most of this opportunity, they can draw from the lessons learned in coping with previous disasters and employ appropriate strategies as they develop their response.

Responses to disaster can be considered in terms of two phases, beginning with immediate rescue and relief responses followed by longer term recovery that includes actions to decrease vulnerability in the future.

\section{Rescue and relief phases of disaster response: waste management and resettlement concerns}

In the rescue and relief phase implemented during the initial weeks after the disaster, the potential impact of actions taken to alleviate human suffering can also have unforeseen negative effects on the environment that could compromise long-term recovery. For example, providing fuel wood instead of kerosene or natural gas can lead to further deforestation in the surrounding region, increasing the threat of subsequent landslides. Decisions taken for short-term measures such as resettlement can also have long lasting consequences should resettlement be undertaken on habitat of particular importance for particular ecosystem functions such as watershed protection. Longer term recovery will often require concerted and directed action for both people and their environment.

Of the many activities in the relief phase, waste management and resettlement of affected people can have particularly profound influences on ecosystem function. In terms of the direct causes of environmental degradation, both can result in habitat loss or fragmentation, pollution, and spread of invasive non-native species that can hamper recovery of native vegetation. Resettlement can also have the unintended consequence of overexploitation of natural resources as people living in new situations search for food, wood for heat and cooking, and natural products to consume or sell for income.

Materials brought to disaster sites to support resettlement of displaced people may have the unintended consequence of carrying invasive nonnative species to new habitats. Invasive species were a critical concern in the recovery plans for Hurricane Katrina, which hit New Orleans in 2006. The Formosan subterranean termite (Coptotermes formosanus) is native to China but was accidentally introduced into the U.S., probably in shipping crates, and has since invaded at least nine southern states. Prior to Hurricane Katrina, the Formosan termite was annually responsible for an estimated $\$ 100$ million in damage to homes and businesses in the New Orleans area (UGA CAES 2005). Following Hurricane Katrina, the Louisiana Department of Agriculture and Forestry passed the Formosan Termite Initiative Act; essentially a quarantine on debris from the disaster. The act noted that "The hurricane has left millions of tons of wood debris, including debris infested with Formosan 
Termites," (Louisiana Department of Agriculture 2005:1) and that "Imposition of this quarantine is required to prevent the spread of Formosan termites and infestation of areas, homes and structures that are not currently infested, or which are to be built or reconstructed" (Louisiana Department of Agriculture 2005:2). The effectiveness of the quarantine has yet to be assessed but recognizing its necessity was an important first step.

The Asian Development Bank (ADB 2005) found that post-tsunami clean up actions around the Andaman Sea were affecting the environment because municipalities dumped waste into wetlands with resulting disruption of drainage systems and flood retention areas, increasing the potential for waterborne diseases. Some of the proposed resettlement sites would also threaten biodiversityrich areas, therefore $\mathrm{ADB}$ recommended that resettlement sites should be located with an adequate buffer between them and the biologically sensitive sites, and ensure that the number of households relocated were within the carrying capacity of the area.

In the case of the central China earthquake, the issues of waste were also daunting. China's military disposed of more than 8 million cubic meters of earthquake waste, enough to fill the inner space of the "Bird's Nest" Olympic stadium in Beijing almost 16 times (WRI 2008). In addition, the treatment of large numbers of injured people resulted in significant amounts of medical waste that required careful disposal to avoid the spread of disease, including to animals. Finally, because central China is an important producer of many chemicals for agriculture, damages included the release of chemicals, such as phosphorus and ammonia, into the environment (RSC 2008).

For Haiti, the issue of waste is more than daunting. Haiti's president was quoted as saying there was enough rubble to "fill 1000 trucks for 1000 days" (Fletcher 2010). Together, the volume of rubble plus medical waste resulting from treatment of the many injured people are posing potential threats to the environment upon which people depend for food, water, and shelter. Failure to address these threats to ecosystem services in the short term, will, in the longer term, mean delayed restoration of people's livelihoods.

Potential collateral damage relating to postdisaster waste management includes invasive species presenting another important, but often overlooked, threat. The giant waves of the Indian ocean tsunami, among other things, carried invasive alien species such as prickly-pears (Opuntia sp.) and salt-tolerant mesquite (Prosopis sp.) farther inland in Sri Lanka, reaching protected areas such as Yala National Park. These non-native species are replacing the native species that are more palatable to Sri Lanka's livestock and wildlife (UNEP 2005). Given these potential impacts of actions taken during the rescue and relief phases of disaster recovery, decisions taken at this time should also include considerations of environmental impacts.

\section{LONG-TERM RECOVERY PLANNING}

IUCN and other organizations have been involved at ground level in recovery assistance for many of the recent extreme events including the Pakistan and Sichuan earthquakes, Hurricane Mitch, and the Indian Ocean tsunami. Taken together, the lessons learned from these experiences and information gleaned from the literature have provided guidance to support disaster recovery planning that effectively incorporates environmental considerations. As planning for long-term recovery in Haiti begins, integrating environmental considerations into disaster recovery should be guided by several key elements: understanding the status and trends of biodiversity, capacity to integrate conservation into disaster recovery, and policy support for integrating environmental conservation.

\section{Understanding status and trends of biodiversity}

Including environmental considerations in disaster recovery planning requires knowledge at two levels. First, an understanding of the general status and trends of biodiversity prior to the disaster event is necessary to set a baseline from which to measure change. Second, an ongoing environmental monitoring program must be implemented to gauge the impact of disaster recovery actions on the environment.

In terms of the status of biodiversity in Haiti, the Caribbean Islands have been included as one of 25 hotspots identified by Conservation International based on the concentration of endemic species in this region and the amount of habitat loss reported (Myers et al. 2000). The National Biodiversity 
Strategy and Action Plan for Haiti, prepared in 1999 (see CBD 2008), highlights the high level of endemicity in Haiti's fauna (up to $75 \%$ endemic, especially invertebrates) and flora (37\% endemic including approximately 300 species of Rubiaceae, 300 species of Orchidaceae, 330 species of Asteraceae, 300 Graminae, and three species of conifers (Pinus occidentalis, Juniper juniperus, Juniperus ekmanii).

The IUCN Red List of Threatened Species (www.i ucnredlist.org) identifies 92 species in Haiti and the DR that are threatened including endemic species such as the Hispaniolan Solenodon (Solenodon paradoxus), a nocturnal, venomous, insectivorous mammal, and 42 species of Eleutherodactylidae, a species-rich taxon of frogs that is supposedly 'adapted for success' because of its characteristic of direct development from egg to frog, bypassing the typical tadpole stage. Overall, the reptiles and amphibians are most threatened (Fig. 1).

\section{Capacity to implement and integrate conservation into disaster recovery}

In addition to knowledge, capacity to respond to this event will be an important element of success. The sheer scope of the disaster in Haiti has called on all available local human capacity, as well as substantial assistance from outside. Ecosystem rehabilitation and restoration will require support from the people living in the area as well as government departments and donors, in addition to those dealing with humanitarian relief in response to the immediate impacts of the tragedy. Guidance to support the planning and implementation of ecosystem rehabilitation is already available, for example, Miththapala (2008) and Mitsch and Jorgensen (2004). However, those overseeing the recovery need to be given a mandate to use these tools. Obtaining such a mandate may be facilitated by a rationale for including ecosystem recovery as a means of supporting livelihoods, which has been developed by the Society for Ecological Restoration International and IUCN's Commission on Ecosystem Management (2004).

Perhaps just as important for recovery is the need to ensure that this capacity is focused and coordinated toward identified priorities and areas of need. In terms of biodiversity, Haiti began drafting a National Biodiversity Strategy and Action Plan (NBSAP) under the support of a World Bank grant, through the Global Environment Facility 9GEF, wherein five priorities were identified, including:
1. Conservation of biological diversity through in-situ conservation, conservation and sustainable use of natural areas providing water resources and buffering natural risks and hazards, conservation and valorization of genetic resources, and ex-situ conservation.

2. Education, identification, and monitoring of biodiversity components.

3. Sustainable use of components of biological biodiversity.

4. Control of alien species and management of Genetically Modified Organisms.

5. Creation of a new legal, regulatory, and institutional framework to manage Haitian biodiversity.

More detailed discussion of the role of biodiversity conservation in buffering the impact of natural hazards was included in (i) specific projects to strengthen local communities' capacities to deal with natural risks and hazards, such as increased participation in disaster management decision support systems and in awareness raising activities, and (ii) plans for finalization and implementation of an action plan for preventing natural risks and hazards. Unfortunately, the NBSAP was never completed because the funding was withdrawn following the controversial elections of 2000 (CBD 2008).

\section{Policy support for integrating environmental conservation in disaster recovery}

Important lessons have already been learned from previous disasters about the need for supporting polices in aid of long-term environmental management. First, mandating environmental impact assessment (EIA) requirements for both short and longer term infrastructure is essential. Then, policies on building construction codes may need to be established for zoning types of construction and types of building materials used. In addition, as the earthquake may have severely altered environments, rehabilitation may require establishment and enforcement of protected areas or planted forests of fast-growing trees as buffer zones.

China established a goal to recover from their 2008 earthquake disaster within three years but this is a 
Fig. 1. International Union for Conservation of Nature Red List status for Haitian species that have been identified as threatened (CR - Critically Endangered; EN - Endangered; VU - Vulnerable; IUCN 2010)

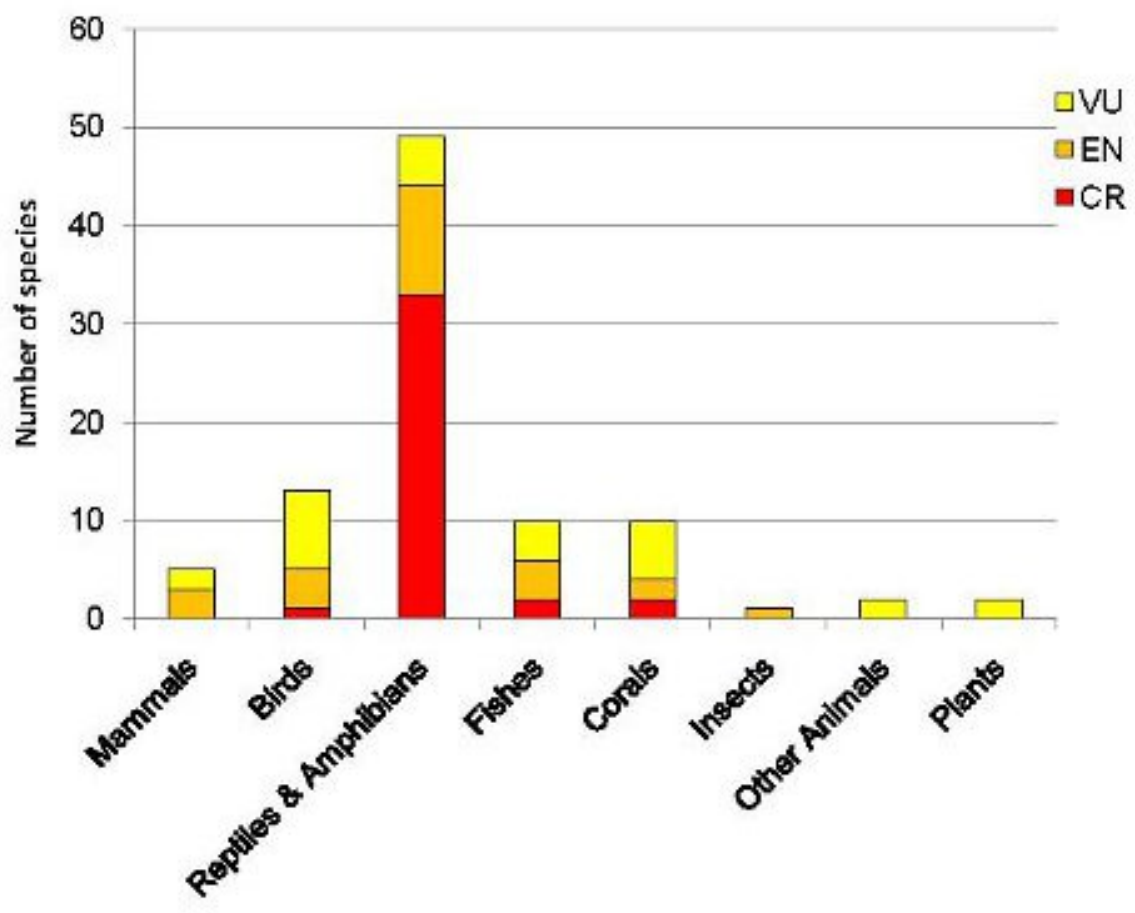

country with almost limitless capacity and wellorganized infrastructure. The situation for Haiti is quite different. Recovery will take much longer both in terms of the human-made infrastructure and the ecosystems that support human existence. The specter of climate change and increased severity of hurricanes (Gray 2008) compounds the challenges.

In developing longer term plans, lessons learned from previous postdisaster recovery efforts suggest that relevant policies should include:

- Ecosystem policies that foster spatial and biological heterogeneity when choosing sites and improve ecological resilience by reestablishing key ecological processes upon which agricultural and natural communities depend, e.g., hydrological cycles, nutrient cycles and flows;

- Socioeconomic policies that support infrastructure development that minimizes impact on ecosystems, creates new and potentially sustainable resources, and adds to the diversity of economic resources available.

\section{OTHER CONSIDERATIONS IN DISASTER MANAGEMENT APPROACHES}

When the knowledge, capacity, and policies are in place, then effective action can follow. That action should be taken with a landscape-scale approach in mind rather than working farm by farm. Landscapescale management acts on a scale broad enough to recognize the role of all critical influencing factors and of stakeholders that shape land use decisions (McNeely and Scherr 2003, Scherr and McNeely 2007). Good landscape management will fulfill societal needs by equitably balancing trade-offs between the productive, social, and environmental requirements of current land use.

Developing the ecosystem recovery plans requires balancing the options and needs. Many different stakeholders are involved including local villagers, city dwellers who depend on products from the region, expatriate Haitians providing financial support to relatives, donors who often have their own priorities, and international tourists who bring in valuable income. Each may want something different and the choices made will need to balance the demands. Tools are available to help with this 
exercise, such as developing scenarios, estimating flows, and conducting strategic environmental impact assessments. In the end though, planners have to recognize that the ideal of a 'win-win' result is unlikely and that they will need to find the best 'win more-lose less' option.

Blaikie et al. (2005), in the aftermath of the Indian Ocean tsunami, suggested that effective recovery and reduction of future vulnerability for local people depended on:

- Recognizing that ecosystem services provide the basis for sustainable reconstruction and reduction of future vulnerability;

- Long-term monitoring of both ecological and socioeconomic parameters and a management strategy that encourages adaptation to changing circumstances;

- $\quad$ Addressing issues of governance and politics at all levels, local to international;

- Providing a clear articulation of the rationale for including biodiversity conservation concerns in reconstruction planning;

- Resolving resource tenure issues with all involved stakeholders;

- Ensuring full participation of all stakeholders affected by the disaster in the recovery process;

- Including local solutions and "ways of doing things" and local institutions in recovery planning and implementation.

In terms of environmental management, IUCN (2005) provided additional principles that should be incorporated in earthquake recovery planning.

(1) Take the opportunity to do things better. Do not simply plan to recreate what was there before. "Build back better" is a recognized strategy in physical infrastructure planning postdisaster (Kennedy et al. 2008), and it is a strategy that should also be applied to environmental restoration. At the same time, it is becoming clear that we may be faced with novel and disappearing climates in some places (Williams et al. 2007) and that increasing urbanization may change land use patterns from what they were before. In the face of such global change, 'restoring' ecosystems may be a less viable option than working to restore ecosystem services and functionality (Jackson and Hobbs 2009).

(2) Create a plan with flexibility to adapt. Assume that the plan will change as it is being implemented. Gunderson (2010) noted the complexity of social and ecological systems in responding to natural disasters and the need to build learning and adaptive capacity.

(3) Do not assume a "one size fits all" strategy. No single solution will be appropriate in every circumstance and not all areas affected by the earthquake will need active rehabilitation. Given that resources will be finite, choose the most viable areas in which to work.

(4) Avoid further damage to the environment through the actions taken. As noted earlier in this review, actions taken in the rescue and relief phases can have longer term consequences for environmental recovery.

\section{The influence of climate change on recovery planning.}

Finally, the response plan should include the potential impacts of climate change, both in terms of adaptation and mitigation. Projected temperature increases for this region are $\sim 2^{\circ} \mathrm{C}$ along with a decrease in precipitation of up to $5 \%$ by 2050 (Lal et al. 2002). Sea level will rise and, with increasing temperatures, there will be an increase in frequency and severity of extreme events such as hurricanes (Emmanuel 2005). The result will be devastating for areas that have lost their native vegetation.

Haiti is recognized as one of the most vulnerable countries in terms of climate change adaptation (Brooks et al. 2005), for example, in adapting its fisheries in the face of climate change (Allison et al. 2009). Responding to the earthquake will only further challenge the scarce capacity and institutional vulnerabilities.

The Fourth Assessment Report of the IPCC (IPCC 2007) cited many possible adaptation responses, from technology, i.e., building infrastructure, to behavioral, i.e., changing food or recreation choices, to managerial, i.e., changing agricultural practices, and policy options, i.e., integration of 
adaptation into planning policy. However, the report also notes that the potential effectiveness or risks associated with these options remain largely unknown while each presents significant implementation challenges in terms of impacts on people, environments, and economies.

Adaptation strategies will, by necessity, vary with location and situation and will include a variety of approaches from infrastructure to application of technologies. As climate change is an extremely dynamic process and uncertainties remain, adaptation measures will need to be flexible and responsive to changing situations (Fankhauser et al. 1999). Some adaptation responses such as physical infrastructure are long-term investments that are difficult to change once in place as compared with ecosystem management activity that can respond much more quickly to changing needs. Therefore, such measures should be complemented by more responsive adaptation strategies such as ecosystembased approaches.

In supplying the services that support the economy and society to function, ecosystems should be considered as integral elements of the infrastructure for postdisaster recovery and development (Emerton 2006). The natural infrastructure provided by well-functioning ecosystems has several advantages over physical infrastructure, such as dams and levees. As noted above, ecosystem management planning is much more flexible and can be altered more quickly should changes in approach be needed. Ecosystem-based adaptation is not 'new technology' but rather implements a strategy that people have employed for many thousands of years in response to environmental and climate change. Finally, ecosystem-based adaptation can be cost-effective compared with many types of infrastructure, and most ecosystem-based adaptation activities can be implemented immediately. Therefore, they are of particular importance for the rural poor, who often do not have access to alternative adaptation responses (Secretariat of the CBD 2009).

Given these lessons gleaned from managing responses to other disasters as well as current knowledge of complicating factors such as impacts of climate change, any actions taken as part of the earthquake recovery plan should include adapting to the future. This can be achieved by rethinking which species are to be used for reforestation and adjusting locations of villages to reduce vulnerability to future threats.

\section{CONCLUSIONS}

The link between ecosystem management and natural disasters means effective ecosystem management before a disaster occurs can help to minimize potential impacts of such natural hazards. Further, in the recovery and restoration phases of humanitarian assistance, integrating ecosystem considerations can support sustainable development and reconstruction of the regions affected.

Throughout this review we have used available evidence in support of effective ecosystem management as an important means by which to mitigate the impacts of extreme natural events such as hurricanes, earthquakes, and floods. Factors involved in this mitigation include increasing resilience of systems to respond to disturbances, availability of basic materials for food and shelter postdisaster and in support of livelihoods in the longer term.

Evidence also demonstrates that the recovery effort itself could damage the environment's ability to deliver those services through additional habitat destruction, overexploitation of available resources, pollution from waste, and facilitation of invasive species establishment. All planning efforts should take all possible measures to ensure that these impacts are avoided.

The time frame for including ecosystem recovery in reconstruction efforts is long, and yet it is absolutely worth including in these plans because, as demonstrated throughout this review: sustainable livelihoods, both immediately and in the long term, will depend on ecosystem services; and restoring habitats will improve the capacity of both ecosystems and people to withstand future extreme natural events.

The earthquake in Haiti was certainly a tragedy of enormous proportion, building on an already fragile situation for people and the environment. It will take an immense and coordinated effort to support recovery from its impact. However, it is also an opportunity to unite people and create a better future that includes sustainable ecosystem services in support of development, and an opportunity to take measures to mitigate and adapt to climate change in the effort. Is it too much to expect Haiti to recover by 2020 and to do so through ambitious environmental management such as achieving $25 \%$ forest cover? Without ecosystem objectives in the recovery plan, Haiti could be doomed to a never 
ending cycle of soil degradation, vegetation loss, and poverty. With ecosystem-based recovery, Haiti could enter a time of steady environmental improvement leading to improved human wellbeing.

Responses to this article can be read online at: http://www.ecologyandsociety.org/vol16/iss1/art13/ responses/

\section{LITERATURE CITED}

Allison, E. H., A. L. Perry, M. C. Badjeck, W. N. Adger, K. Brown, D. Conway, A. S. Halls, G. M. Pilling, J. D. Reynolds, N. L. Andrew, and N. K. Dulvy. 2009. Vulnerability of national economies to the impacts of climate change on fisheries. Fish and Fisheries 10(2):173-196.

Asian Development Bank (ADB). 2005. Assessment of tsunami recovery implementation in Hambantota district. Asian Development Bank, Manila, Phillipines. [online] URL: http://www.adb.org/Doc uments/Reports/Rebuilding-Sri-Lanka/Hambantotateam.pdf.

Blaikie, P., S. Mainka, and J. McNeely. 2005. The Indian Ocean tsunami: reducing risk and vulnerability to future natural disasters and loss of ecosystems services. International Union for Conservation of Nature Information Paper, February 2005. International Union for Conservation of Nature, Gland, Switzerland. [online] URL: http: //data.iucn.org/dbtw-wpd/edocs/Rep-2005-006.pdf

Brooks, N., W. N. Adger, and P. M. Kelly. 2005. The determinants of vulnerability and adaptive capacity at the national level and the implications for adaptation. Global Environmental Change 15 (2):151-163.

Convention on Biological Diversity (CBD). 2008. Status of Haiti NBSAP. Convention on Biological Diversity, Montréal, Québec, Canada. [online] URL: http://www.cbd.int/doc/world/ht/ht-nbsap-01en.pdf.

Daily, G. C., editor. 1997. Nature's services: societal dependence on natural ecosystems. Island Press, Washington, D.C., USA
Danielsen, F., M. K. Sørensen, M. F. Olwig, V. Selvam, F. Parish, N. D. Burgess, T. Hiraishi, V. M. Karunagaran, M. S. Rasmussen, L. B. Hansen, A. Quarto, and N. Suryadiputra. 2005. The Asian tsunami: a protective role for coastal vegetation. Science 310:643.

Diamond, J. 2005. Collapse: how societies choose to fail or survive. Penguin Books, London, UK.

Emerton, L. 2006. Counting coastal ecosystems as an economic part of development infrastructure. Ecosystems and Livelihoods Group Asia, International Union for Conservation of Nature, Colombo, Sri Lanka.

Emmanuel, K. 2005. Increasing destructiveness of tropical cyclones over the past 30 years. Nature 436:686-688.

Fankhauser, S., J. B. Smith, and R. S. J. Tol. 1999. Weathering climate change: some simple rules to guide adaptation decisions. Ecological Economics 30(1):67-78.

Feagin, R. E., N. Mukherjee, K. Shanker, A. H. Baird, J. Cinner, A. M. Kerr, N. Koedam, A. Sridhar, R. Arthur, L.P. Jayatissa, D. L. Seen, M. Menon, S. Rodriguez, Md. Shamsuddoha, and F. DahdouhGuebas. 2010. Shelter from the storm? Use and misuse of coastal vegetation bioshields for managing natural disasters. Conservation Letters 3 (1):1-11.

Fletcher, P. 2010. Haiti shelter emergency as rain turns camps to mud. Reuters, 18 February. [online] URL: http://www.reuters.com/article/idUSTRE61H 59Q20100218.

Food and Agriculture Organization Global Information and Early Warning system (FAO GIEWS). 2008. Wenchuan earthquake - Impact on agriculture, livestock and food security in affected areas, and implications for China (Update). Food and Agriculture Organization, Rome, Italy. [online] URL: http://www.fao.org/giews/english/shortnews/ china080530.htm.

Government of China. 2008. The State overall planning for post- Wenchuan earthquake restoration and reconstruction. (Public opinion soliciting draft). August 2008. National Development and Reform Commission, People's Republic of China, Beijing, China. 
Gray, W. M. 2008. Hurricanes and climate change. George C. Marshall Institute, Washington, D.C., USA. [online] URL: http://ruby.fgcu.edu/courses/tw imberley/EnviroPhilo/HurricanesAndClimateChange. pdf.

Gunderson, L. 2010. Ecological and human community resilience in response to natural disasters. Ecology and Society 15(2): 18. [online] URL: http://www.ecologyandsociety.org/vol15/iss2/ art18/.

Holt-Giménez, E. 2002. Measuring farmers' agroecological resistance after Hurricane Mitch in Nicaragua: a case study in participatory, sustainable land management impact monitoring. Agriculture, Ecosystems \& Environment 93(1-3):87-105.

Intergovernmental Panel on Climate Change (IPCC). 2007. Summary for policymakers. In M. L. Parry, O. F. Canziani, J. P. Palutikof, P. J. van der Linden and C. E. Hanson, editors. Climate change 2007: impacts, adaptation and vulnerability. Contribution of Working Group II to the Fourth Assessment Report of the Intergovernmental Panel on Climate Change. Cambridge University Press, Cambridge, UK. [online] URL: http://www.ipcc.ch/ pdf/assessment-report/ar4/wg2/ar4-wg2-spm.pdf.

International Union for Conservation of Nature (IUCN). 2005. Recovery from the Indian Ocean tsunami - guidance for ecosystem rehabilitation incorporating livelihoods concerns. International Union for Conservation of Nature, Gland, Switzerland. [online] URL: http://data.iucn.org/dbtwwpd/edocs/Rep-2005-007.pdf.

International Union for Conservation of Nature (IUCN). 2010. IUCN Red List of Threatened Species. International Union for Conservation of Nature, Gland, Switzerland. [online] URL: www.iu cnredlist.org.

Jackson, S. T., and R. J. Hobbs. 2009. Ecological restoration in the light of ecological history. Science 325(5940):567-569.

Kennedy, J., J. Ashmore, E. Babister, and I. Kelman. 2008. The meaning of 'build back better': evidence from post-tsunami Aceh and Sri Lanka. Journal of Contingencies and Crisis Management 16 (1):24-36.

Koch, E. W., E. B. Barbier, B. R. Silliman, D. J. Reed, G. M. Perillo, S. D. Hacker, E. F. Granek, J.
H. Primavera, N. Muthiga, S. Polasky, B. S. Halpern, C. J. Kennedy, C. V. Kappel, and E. Wolanski. 2009. Non-linearity in ecosystem services: temporal and spatial variability in coastal protection. Frontiers in Ecology and the Environment 7(1):29-37.

Lal, M., H. Harasawa, and K. Takahashi. 2002. Future climate change and its impacts over small island states. Climate Research 19:179-192.

Louisiana Department of Agriculture and Forestry, Office of Agricultural and Environmental Sciences. 2005. Imposition of quarantine. Pesticides and Environmental Programs, Baton Rouge, Louisiana, USA. [online] URL: http://www.ldaf.state.la.us/portal/ Portals/0/AES/Horticulture/katrinaquarantine.pdf.

McNeely, J. A., and S. J. Scherr. 2003. Ecoagriculture: strategies for feeding the world and conserving wild biodiversity. Island Press, Washington, D.C., USA.

Millennium Ecosystem Assessment (MA). 2005. Ecosystems and human well-being: synthesis. Island Press, Washington, D.C., USA. [online] URL: http://www.maweb.org/documents/document.356. aspx.pdf.

Miththapala, S. 2008. Integrating environmental safeguards into disaster management. Volume 1 and Volume 2. Ecosystems and Livelihoods Group Asia, International Union for Conservation of Nature, Colombo, Sri Lanka.

Mitsch, W. J., and S. E. Jorgensen. 2004. Ecological engineering and ecosystem restoration. Second edition. John Wiley \& Sons, New York, New York, USA.

Myers, N., R. A. Mittermeier, C. G. Mittermeier, G. A. B. da Fonseca, and J. Kent. 2000. Biodiversity hotspots for conservation priorities. Nature 403:853-858.

Opperman, J. J., G. E. Galloway, J. Fargione, J. F. Mount, B. D. Richter, and S. Secchi. 2009. Sustainable floodplains through large-scale reconnection to rivers. Science 326:1487-1488.

Royal Society of Chemistry (RSC). 2008. China quake hits chemical industry. Royal Society of Chemistry, London, UK. [online] URL: http://www .rsc.org/chemistryworld/News/2008/May/16050802. asp. 
Scherr, S. J., and J. A. McNeely, editors. 2007. Farming with nature: the science and practice of ecoagriculture. Island Press, Washington, D.C., USA.

Secretariat of the Convention on Biological Diversity (CBD). 2009. Connecting biodiversity and climate change mitigation and adaptation: report of the second ad hoc technical expert group on biodiversity and climate change. Technical Series No. 41. Secretariat of the CBD, Montréal, Québec, Canada. [online] URL: http://www.cbd.int/ doc/publications/cbd-ts-41-en.pdf .

Society for Ecological Restoration International and International Union for Conservation of Nature Commission on Ecosystem Management. 2004. Ecological restoration: a means of conserving biodiversity and sustaining livelihoods. Society for Ecological Restoration International, Tucson, Arizona, USA and IUCN, Gland, Switzerland. [online] URL:http://www.ser.org/pdf/Global_Rationale. pdf

United Nations Development Programme (UNDP). 2010. Human development report 2010. The real wealth of nations: pathways to human development. United Nations Human Development Report Office, New York, New York, USA. [online] URL: http://hdr.undp.org/en/reports/global/hdr2010/.

United Nations Environment Programme (UNEP). 2005. After the tsunami: rapid environmental assessment. United Nations Environment Programme, Nairobi, Kenya. [online] URL: http://www.unep.org/ tsunami/tsunami rpt.asp.

United Nations Office for the Coordination of Humanitarian Affairs (UN OCHA). 2005. Update to partners on environmental aspects of the South Asia earthquake. Office for the Coordination of Humanitarian Affairs, Geneva, Switzerland. [online] URL: http://ochaonline.un.org/OchaLinkClick. aspx?link=ocha\&DocId=1003976.

University of Georgia College of Agricultural \& Environmental Sciences (UGA CAES). 2005. The Formosan subterranean termite in Georgia. University of Georgia, Athens, Georgia, USA. [online] URL: http://www.caes.uga.edu/departments/ ent/upmp/termites.html.
Williams, J. W., S. T. Jackson, and J. E. Kutzbach. 2007. Projected distributions of novel and disappearing climates by 2100 AD. Proceedings of the National Academy of Sciences 104(14):5738-42.

World Resources Institute (WRI). 2008. Environmental challenges after China's Sichuan earthquake. World Resources Institute, Washington, D.C., USA. [online] URL: http://earthtrends.wri.org/updates/ node/316. 